\title{
(a) \\ Multidetector Computed Tomography Findings of Persistent Left Superior Vena Cava: A Report of Five Cases
}

\section{Persistan Sol Vena Kava Süperiorun Çok Kesitli Bilgisayarlı Tomografi Bulguları: Beş Olgunun Sunumu}

Murat Beyhan, ${ }^{2}$ Fatih Çelikyay, ${ }^{2}$ Ruken Yüksekkaya, ${ }^{2}$ Ferdağ Almus, ${ }^{2}$ Banu Öztürk, ${ }^{3}$ Handan İnönü ${ }^{4}$

\begin{abstract}
Persistent left superior vena cava is the most common variation of the anomalous venous return to the heart. It may coexist with the right superior vena cava but may also appear on its own. In addition, persistent left superior vena cava is usually asymptomatic and is discovered incidentally. When present, this condition could complicate intravascular procedures or cardiac surgery. Herein, is a report of the multidetector computed tomography findings of five cases with persistent left superior vena cava.
\end{abstract}

Key words: Multidetector computed tomography, persistent left superior vena cava, superior vena cava.

\section{Özet}

Persistan sol vena kava süperior kalbe venöz dönüş anomalilerinin en sık formudur. Sağ vena kava süperior varken persistan sol süperior vena kava görülebileceği gibi, sağ olmadan da olabilir. Genellikle bulgu vermez ve kardiyak girişimsel ve cerrahi işlemler sonrasında rastlantısal olarak tanı alır. Bu olgu sunumunda persistan sol vena kava süperior saptanan beş olgunun çok kesitli bilgisayarlı tomografi bulgularını sunmayı amaçladık.

Anahtar Sözcükler: Çok kesitli bilgisayarlı tomografi, persistan sol vena kava süperior, vena kava süperior.

\footnotetext{
'Department of Radiology, Zile State Hospital, Tokat, Turkey

${ }^{2}$ Department of Radiology, Gaziosmanpaşa University Faculty of Medicine, Tokat, Turkey

${ }^{3}$ Department of Oncology, Gaziosmanpaşa University Faculty of Medicine, Tokat, Turkey

${ }^{4}$ Department of Chest Disease, Gaziosmanpaşa University Faculty of Medicine, Tokat, Turkey
}

\author{
'Zile Devlet Hastanesi, Radyoloji, Tokat \\ ${ }^{2}$ Gaziosmanpaşa Üniversitesi Tıp Fakültesi, Radyoloji Anabilim \\ Dalı, Tokat \\ ${ }^{3}$ Gaziosmanpaşa Üniversitesi Tıp Fakültesi, Onkoloji Anabilim \\ Dalı, Tokat \\ ${ }^{4}$ Gaziosmanpaşa Üniversitesi Tıp Fakültesi, Göğüs Hastalıkları \\ ve Tüberküloz Anabilim Dalı, Tokat
}

Submitted (Başvuru tarihi): 25.06.2013 Accepted (Kabul tarihi): 14.08.2013

Correspondence (iletişim): Murat Beyhan, Department of Radiology, Zile State Hospital, Tokat, Turkey e-mail: m_termeli@hotmail.com 
Persistent left superior vena cava (PLSVC) is the most common variation of the anomalous venous return to the heart affecting about $0.3-0.5 \%$ of the general population $(1,2)$. It can also be associated with $5-10 \%$ of congenital heart disease (3) and usually coexists with the right superior vena cava (RSVC), but this is not always the case $(2,4,5)$. Persistent LSVC is usually asymptomatic and is discovered incidentally. In addition, this condition can present technical difficulties during intravascular procedures or cardiac surgery $(1,5)$. Herein, we present the multidetector computed tomography (MDCT) findings of five cases with PLSVC.

\section{CASE}

Case 1: A 57-year-old male was admitted to the chest disease department of our facility with obstructive sleep apnea disorder. Physical examinations and laboratory results revealed no abnormalities, but posteroanterior chest radiography detected an enlarged mediastinum. Therefore, the patient underwent chest MDCT in the supine position, during maximum inspiration, using an eight-channel MDCT system (GE Healthcare, Milwaukee, WI, USA). Contiguous axial slices with contrast-enhanced CT were undertaken at $5 \mathrm{~mm}$ intervals with $5 \mathrm{~mm}$ collimation at automatically modulated amperage of $120 \mathrm{Kvp}$ (120 to $225 \mathrm{~mA}$ ). All images were obtained at window levels appropriate for the lung parenchyma (window width, 1.500-1.700 HU; window level, -600 or $-700 \mathrm{HU}$ ) and mediastinum (window width, 250-400 HU; window level, 40-50 HU). The images were then reconstructed via a high-resolution algorithm, and the multiplanar reformatted (MPR) images were interpreted in various planes. The MDCT revealed cardiomegaly and aneurysmatic dilatation of the ascending aorta. Furtermore, PLSVC was observed at the left side of the mediastinum and the lateral side of the aortic arch, pulmonary arteries, and left atrium. Furthermore, they were draining into the right atrium via a dilated coronary sinus (Figure la and b). It was draining left jugular and subclavian veins and joining the left brachiocephalic vein (Figure 1c). Chronic fibrotic changes with traction bronchiectasis and peribronchial thickening were also observed.

Case 2: A 63-year-old male had been suffering from abdominal pain for two months prior to being admitted to our radiology department for abdominal ultrasonography (US). A clinical examination revealed no abnormalities,
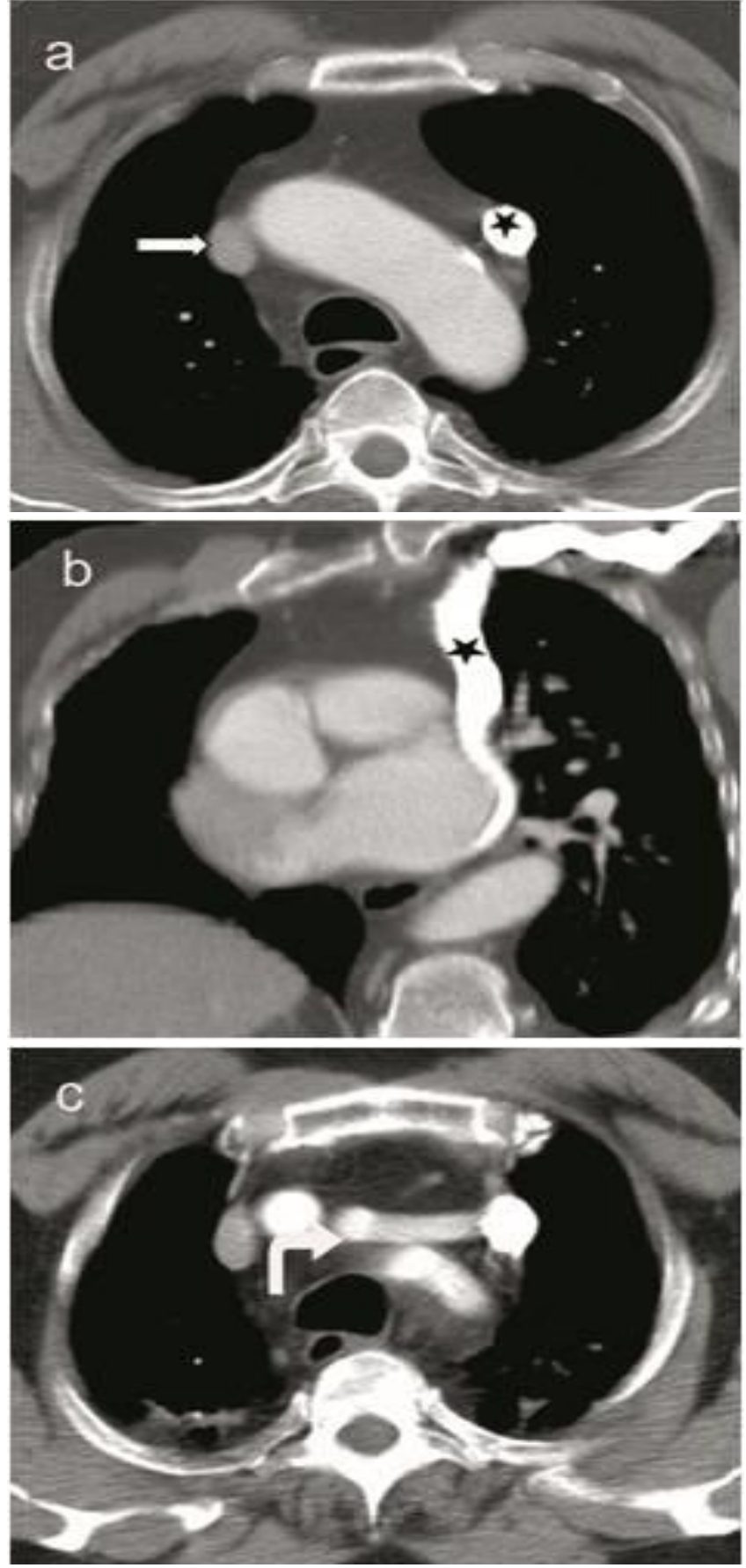

Figure 1a, b, c: An axial MDCT image a) obtained at the level of the aortic arch and a coronal MPR MDCT image b) reveal a left-sided SVC ( $\star$ ) along with a right-sided SVC (white arrow). An axial MDCT image c) obtained at the level of the supraaortic vessels shows a left brachiocephalic vein (curved white arrow).

but laboratory tests showed elevated carbohydrate antigen 19-9 (CA19-9) (635.8 (0-35) U/mL) and carcinoembryonicantigen (CEA) $(9.6(0-5) \mathrm{ng} / \mathrm{mL})$ levels. A pancreatic mass measuring about $2 \times 2 \mathrm{~cm}$ in diameter and multiple metastases at the liver of varying diameters 
were detected on the abdominal US. Diagnostic and staging procedures were then performed. The patient underwent chest MDCT with the same protocol used in Case I, and multiple metastatic nodules of various diameters at the lungs were detected. Moreover, the MDCT showed PLSVC at the left side of the mediastinum and on the lateral side of the aortic arch, pulmonary arteries, and left atrium, with drainage into the right atrium via the coronary sinus (Figure $2 a$ and b) as well as the left jugular and subclavian veins. However, the researchers found no left brachiocephalic vein.
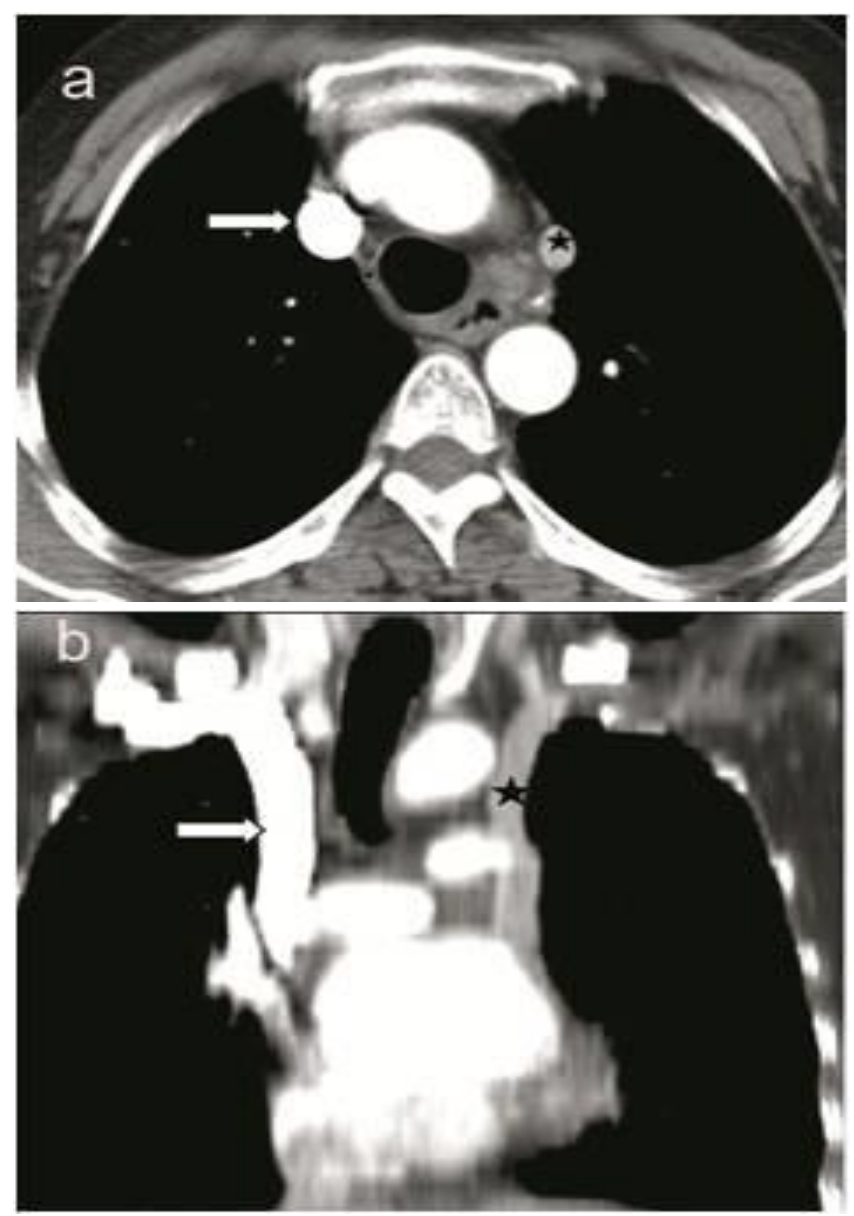

Figure 2a, b: An axial MDCT image a) obtained at the level of the aortopulmonary window and a coronal MPR MDCT image b) reveal a left-sided SVC ( $\star$ ) along with a right-sided SVC (white arrow).

Case 3: A 64-year-old female with chronic renal insufficiency was admitted to our emergency department with dyspnea. The patient's breathing and heart rate were rapid, and laboratory tests revealed a creatinine level of $8.4(0.5-0.9) \mathrm{mg} / \mathrm{dl}$, blood urea nitrogen level of 68.7 (6-23) $\mathrm{mg} / \mathrm{dl}$, and $C$ reactive protein (CRP) level of 13.7 (0-5) $\mathrm{mg} / \mathrm{L}$. The patient's shortness of breath was attributed to a probable pulmonary embolism, and the patient underwent MDCT angiography of the pulmonary artery in the supine position, during maximum inspiration, using an eight-channel MDCT system (GE Healthcare, Milwaukee, WI, USA). Contiguous axial slices with contrastenhanced CT were obtained at $2.5 \mathrm{~mm}$ intervals, 0.875 $\mathrm{mm}$ slice thickness, and $105 \mathrm{Kvp}, 305 \mathrm{~mA}$. All images were obtained at window levels appropriate for the mediastinum (window width, 250-400 HU; window level, 40$50 \mathrm{HU})$. The images were reconstructed with highresolution algorithm, and MPR images were interpreted in various planes. The MDCT angiography revealed PLSVC at the left side of the mediastinum and the lateral side of the aortic arch, pulmonary arteries, and left atrium, with drainage into the right atrium via a dilated coronary sinus No right-sided superior vena cava (SVC) was detected, and we found no left brachiocephalic vein (Figure $3 a$ and b). Additionally, no embolus was observed at the pulmonary arteries. However, the researchers did detect cardiomegaly, pleural effusion with compression atelectasis at both hemithoraces, and a mosaic perfusion pattern at the lungs.
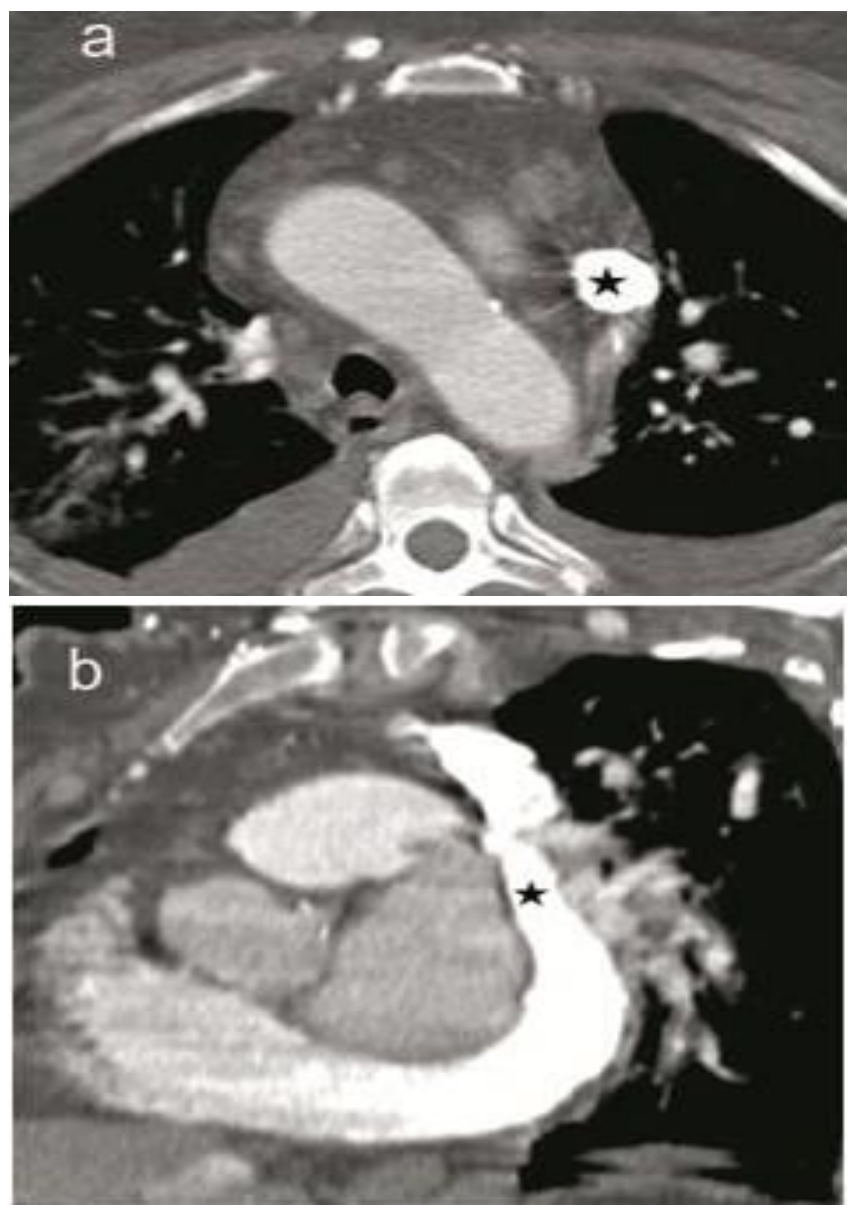

Figure 3a, b: An axial MDCT image a) obtained at the level of the aortic arch and an oblique coronal MPR MDCT image b) show a leftsided SVC ( $\star$ ) and a dilated coronary sinus. There was no right-sided SVC. 
Case 4: A 77-year-old male was admitted to our emergency department with a three-day history of constipation and abdominal pain. The patient's medical history revealed chronic obstructive lung disease (COLD) and cardiac insufficiency. A physical examination was normal, and laboratory tests revealed an erythrocyte sedimentation rate (ESR) of $18 \mathrm{~mm} / \mathrm{h}$, and a CRP level of $50 \mathrm{mg} / \mathrm{dL}$. For the detection of a probable malignancy, the patient underwent chest MDCT using the aforementioned protocol, which revealed PLSVC at the left side of the mediastinum and the lateral side of the aortic arch, pulmonary arteries, and left atrium, with drainage into the right atrium via a dilated coronary sinus. The researchers observed no left brachiocephalic vein (Figure $4 a$ and b). Cardiomegaly, dilated pulmonary arteries, and pleural effusion at both hemithoraces were found.
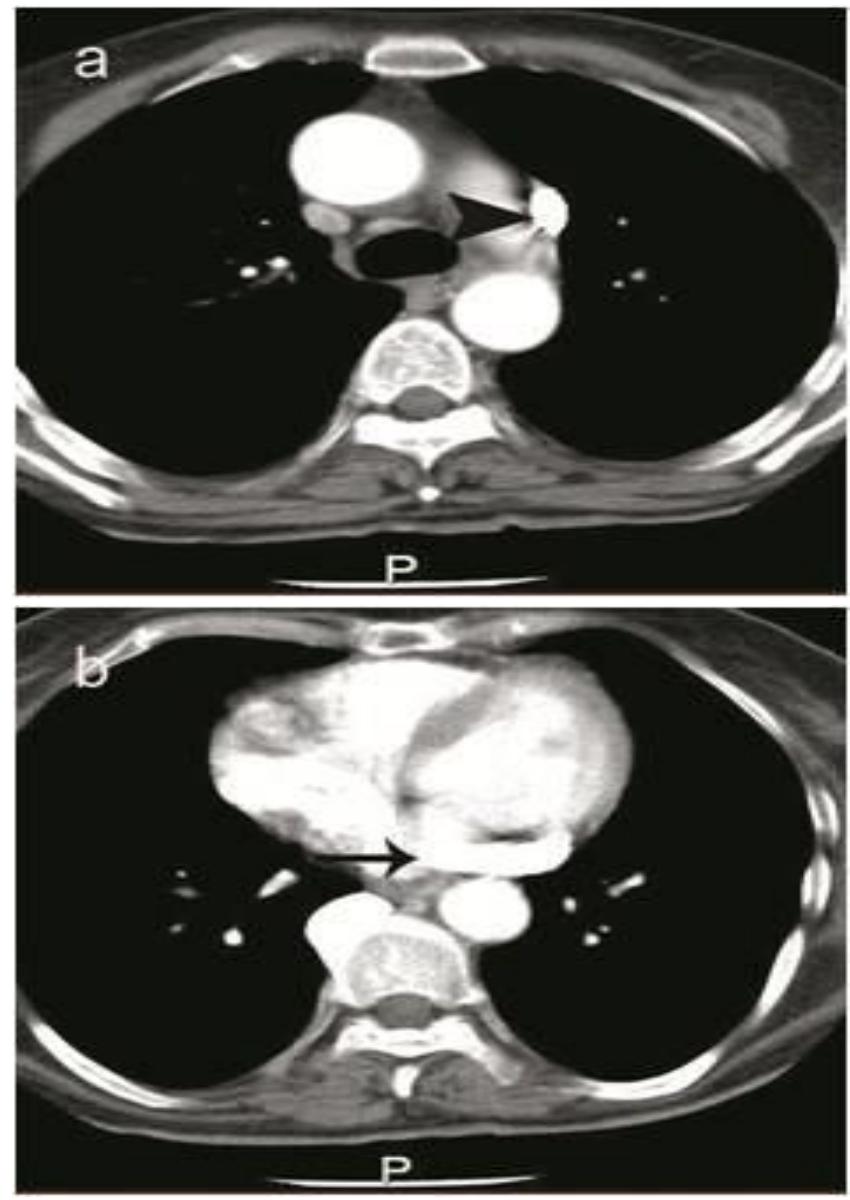

Figure 4a, b: An axial MDCT image a) obtained at the level of the aortopulmonary window shows a PLSVC (arrow head), and an axial MDCT image b) obtained at the cardiac ventricular level reveals a dilated coronary sinus (arrow).

Case 5: A 55-year-old female patient was admitted to our oncology department with abdominal pain and weight loss. A cholecystectomy was performed, and a pathological examination revealed poorly differentiated adenocarcinoma of the gall bladder with serosa and colonic invasion. Radiation therapy and systemic chemotherapy were administered; however, after completing the treatment, liver metastases developed. For re-staging, the patient underwent chest MDCT using the same protocol as the other cases, and PLSVC was discovered at the left side of the mediastinum and the lateral side of the aortic arch, pulmonary arteries, and left atrium, with drainage into the right atrium via a dilated coronary sinus. However, no left brachiocephalic vein was detected (Figure 5a and b). Furthermore, the MDCT revealed a dilated ascending aorta, a few nodules with ground glass opacity at the lungs, and dilated biliary tracts.
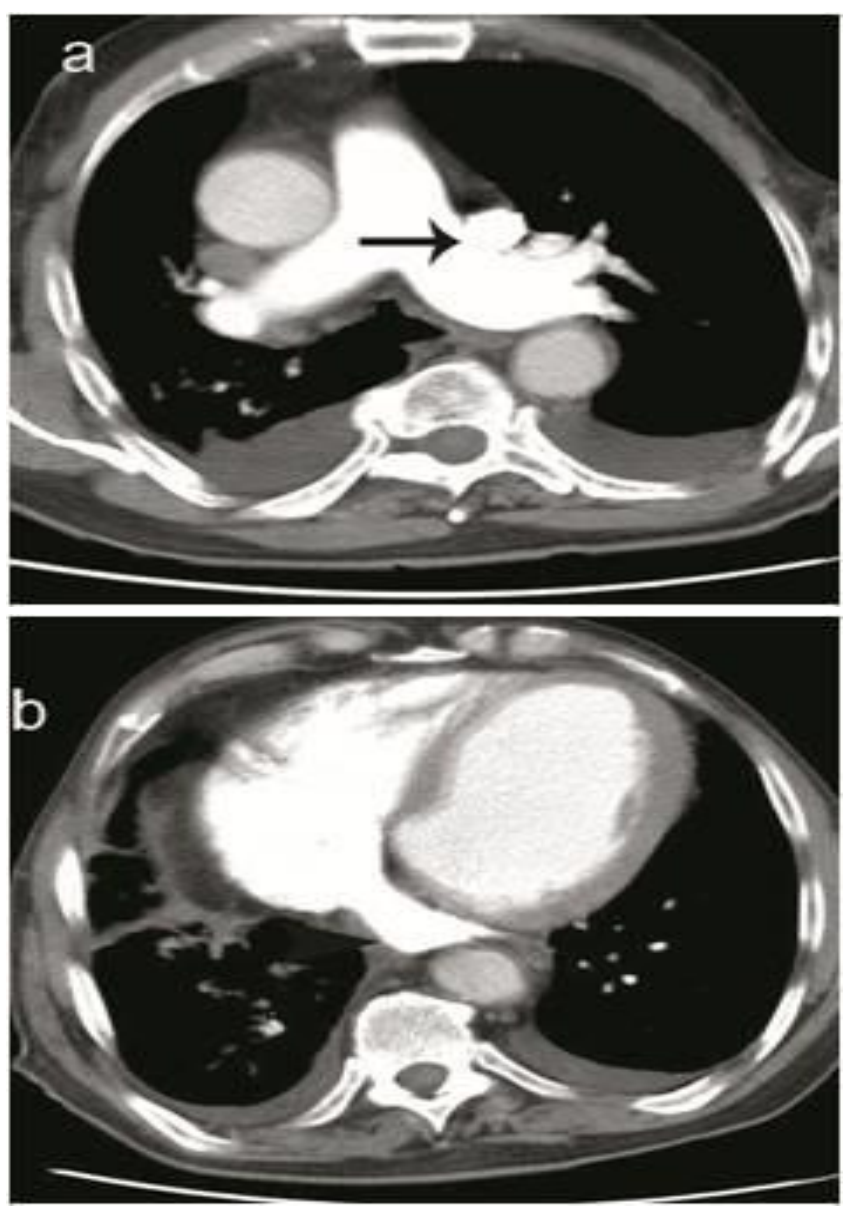

Figure 5a, b: An axial MDCT image a) obtained at the level of the pulmonary arteries shows a PLSVC (black arrow), and an axial MDCT image b) obtained at the cardiac ventricular level reveals a dilated coronary sinus.

\section{DISCUSSION}

The anterior cardinal vein (ACV) and the posterior cardinal vein drain the cranial and caudal parts of the embryo, respectively. In addition, the left brachiocephalic vein develops and connects the cranial portions of the two $A C V_{s}$ in the first eight gestational weeks. The caudal part of the right ACV then becomes the normal RSVC, and the 
left ACV caudal to the left brachiocephalic vein regresses and forms the oblique ligament and the vein of Marshall. If this portion fails to involute, it becomes a PLSVC (1). John Marshall published the first report of the great anterior veins of the thoracic region in humans and mammals in 1850, which including a description of PLSVC (6).

Persistent LSVC can occur in several anatomic variations. If bilateral SVC is present, left brachiocephalic veins may be completely absent in up to approximately $65 \%$ of the patients (6). In the current cases, no brachiocephalic veins were detected, with the exception of Case I. Persistent LSVC coexists with RSVC in up to $80-90 \%$ of cases, but isolated PLSVC is possible, as was seen in Case III. However, this is very rare (7).

In most of the cases with PLSVC, drainage into the right atrium via the coronary sinus occurs, resulting in no hemodynamic consequence. However, in approximately 10 $20 \%$ of cases, drainage takes place via the left atrium, either through an unroofed coronary sinus or in a straight-line fashion into the roof of the left atrium or through the left superior pulmonary vein (6). In all of the current patients, drainage occurred in the right atrium via the coronary sinus.

Patients with PLSVC can have a variety of cardiac anomalies, such as atrial septal defect, a bicuspid aortic valve, coarctation of the aorta, coronary sinus ostial atresia, and cor triatriatum, and these issues are more commonly seen with the concomitant absence of the RSVC (8). The most frequently associated extracardiac anomaly is esophageal atresia (6), but in the present cases, no cardiac or extracardiac anomalies were detected.

Patients with PLSVC can present technical difficulties during intravascular procedures, for example Swan-Ganz catheterization, the insertion of pacing systems, cardiac catheterization, cardiac dialysis, or the cardiac surgery itself $(4,5)$. Serious complications have also been reported when pacemaker leads or catheters have been inserted via the PLSVC (8). In addition, this condition can cause problems during central venous catheterization since accessing the coronary sinus can cause hypotension, angina, perforation of the heart, tamponade, and arrest. Furthermore, pacemaker implantation can also be difficult due to the circuitous path taken by the electrode, which can lead to the inability to obtain a stable electrode position and sustained capture. Moreover, in cardiopulmonary bypass, isolated PLSVC impairs the use of retrograde cardioplegia (7). Another problematic situation can occur during heart transplantation when the coronary sinus must be dissected carefully to permit re-anastomosis of the PLSVC to the right atrium (8). In the absence of an RSVC, central venous access should be made via the femoral vein in patients with PLSVC. During right-sided open-heart surgical procedures, drainage should be done by inserting a separate cannula. If the PLSVC drains into the left atrium and creates a large right-to-left shunt, surgical correction should be undertaken by central venous access via the femoral vein (7). In addition, PLSVCs may predispose the heart to arrhythmia owing to the close proximity of the dilated coronary sinus to the final position of the left-sided primitive pacemaking tissue (5). When PLSVCs are present, electrocardiography often shows an abnormal $\mathrm{P}$-wave axis and a normal or shortened PR interval. In addition, on chest $X$-ray, a crescentshaped shadow of the PLSVC can be seen at the aortic knob or left upper mediastinum. After the insertion of a pulmonary artery catheter into the left subclavian or jugular vein, a control chest $\mathrm{X}$-ray can give the false appearance that the catheter has passed through the vessel (7). However, transthoracic echocardiography can be used to reveal the dilated coronary sinus and the diagnosis can be confirmed with the use of a saline contrast ("bubble study") echocardiography. Single or multiplane transesophageal echocardiography and radionuclide angiocardiography have also been used to establish a diagnosis. Multidetector CT or magnetic resonance venography can also be employed to diagnose this condition and are useful for ruling out variations in the typical anomalous venous course (8). In addition to the axial images, MPR images are also important for the detection of PLSVCs and the evaluation of the presence of an RSVC, left brachiocephalic vein, and other vascular and cardiac anomalies. Furthermore, MPR allows for the evaluation of the chest in more than one plane to show the drainage of the PLSVC into the heart.

In conclusion, radiologists and clinicians should be aware of PLSVC and its variations in order to avoid possible complications and should use MDCT to aid in the diagnosis of this condition. Therefore, it is beneficial to be aware of the presence of PLSVC via MDCT before invasive procedures are performed.

\section{CONFLICTS OF INTEREST}

None declared.

\section{AUTHOR CONTRIBUTIONS}

Concept - M.B., F.Ç., R.Y., F.A., B.Ö., H.I.; Planning and Design - M.B., F.Ç., R.Y., F.A., B.Ö., H.I.; Supervision M.B., F.Ç., R.Y., F.A., B.Ö., H.I.; Funding - M.B., R.Y., 
B.Ö., H.I.; Materials - R.Y., B.Ö., H.i.; Data Collection and/or Processing - M.B., F.A., F.Ç.; Analysis and/or Interpretation - M.B., R.Y., F.Ç.; Literature Review - M.B., R.Y., F.A.; Writing - M.B., F.Ç., R.Y., F.A., B.Ö., H.I. ; Critical Review - M.B., R.Y., F.Ç., B.Ö., H.I., F.A.

\section{YAZAR KATKILARI}

Fikir - M.B., F.Ç., R.Y., F.A., B.Ö., H.İ.; Tasarım ve Dizayn - M.B., F.Ç., R.Y., F.A., B.Ö., H.I.; Denetleme M.B., F.Ç., R.Y., F.A., B.Ö., H.I.; Kaynaklar - M.B., R.Y., B.Ö., H.I.; Malzemeler - R.Y., B.Ö., H.I.; Veri Toplama ve/veya işleme - M.B., F.A., F.Ç.; Analiz ve/veya Yorum M.B., R.Y., F.C..; Literatür Taraması - M.B., R.Y., F.A.; Yazıyı Yazan - M.B., F.Ç., R.Y., F.A., B.Ö., H.I..; Eleştirel Inceleme - M.B., R.Y., F.Ç., B.Ö., H.i., F.A.

\section{REFERENCES}

1. Fang CC, Jao YT, Han SC, Wang SP. Persistent left superior vena cava: multi-slice CT images and report of a case. Int J Cardiol 2007; 121:112-4. [CrossRef]

2. Korkmaz L, Akyüz AR, Erkuş ME, Topal C. Isolated persistent left superior vena cava with absent right superior vena cava in two cases. Arch Turk Soc Cardiol 2011; 39:501-4. [CrossRef]
3. Parker MS, Rosado-de-Christenson ML, Abbott GF. Teaching Atlas of Chest Imaging. 1th ed. New York: Thieme; 2005.

4. Biffi M, Boriani G, Frabetti L, Bronzetti G, Branzi A. Left superior vena cava persistence in patients undergoing pacemaker or cardioverter-defibrillator implantation: a 10-year experience. Chest 2001; 120:139-44. [CrossRef]

5. Benson R E-C, Songrug T. CT appearance of persistent left superior vena cava, anomalous right superior pulmonary venous return into the right-sided superior vena cava and a sinus venosus-type atrialseptal defect. $\mathrm{Br} J$ Radiol 2009; 82:e235-9. [CrossRef]

6. Povoski SP, Khabiri H. Persistent left superior vena cava: Review of the literature, clinical implications, and relevance of alterations in thoracic central venous anatomy as pertaining to the general principles of central venous access device placement and venography in cancer patients. World J Surg Oncol 201 1; 9:173. [CrossRef]

7. Uçar Ö, Paşaoğlu L, Çiçekçioğlu, Vural M, Kocaoğlu i, Aydoğdu S. Persistent left superior vena cava with absent right superior vena cava: a case report and review of the literature. Cardiovasc J Afr 2010; 21:164-6.

8. Goyal SK, Punnam SR, Verma G, Ruberg FL. Persistent left superior vena cava: a case report and review of literature. Cardiovasc Ultrasound 2008; 6:50. [CrossRef] 